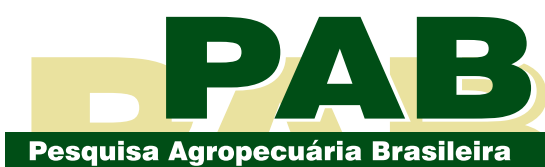

ISSN 1678-3921

Journal homepage: www.embrapa.br/pab

For manuscript submission and journal contents, access: www.scielo.br/pab
Rui Alberto Gomes Junior ${ }^{(1 凶) ~(D), ~}$ Alessandra Ferraiolo de Freitas ${ }^{(1)}$ (iD, Raimundo Nonato Vieira da Cunha(2) (D), Antônio José de Abreu Pina(3) (iD), Higo Otávio Brochado Campos ${ }^{(1)}$ (D) and Ricardo Lopes(2) (iD)

(1) Embrapa Amazônia Oriental, Travessa Doutor Enéas Pinheiro, s/nº, Caixa Postal 48, CEP 66095-100 Belém, PA, Brazil. E-mail: rui.gomes@embrapa.br, alessandra.ferraiolo@embrapa.br, higoocampos@hotmail.com

(2) Embrapa Amazônia Ocidental, Rodovia AM-010, Km 29, Caixa Postal 319, CEP 69010-970 Manaus, AM, Brazil. E-mail: ricardo.lopes@embrapa.br, raimundo.vieira@embrapa.br

3) Marborges Agroindústria S.A., Rodovia Virgílio Serrão Sacramento, Km 56, s/no Caixa Postal 17, CEP 68450-000 Mojú, Pará, Brazil.

E-mail: pina@marborges.com.br

$\bowtie$ Corresponding author

Received

November 03, 2020

Accepted

April 15, 2021

How to cite

GOMES JUNIOR, R.A.; FREITAS, A.F. de; CUNHA, R.N.V. da; PINA, A.J. de A.; CAMPOS, H.O.B.; LOPES, R. Selection gains for the palm oil production from progenies of American oil palm with oil palm. Pesquisa Agropecuária Brasileira, v.56, e02321, 2021. DOI: https://doi. org/10.1590/S1678-3921.pab2021.v56.02321.

\section{Selection gains for the palm oil production from progenies of American oil palm with oil palm}

\begin{abstract}
The objective of this work was to estimate the genetic parameters, correlations, and selection gains for the oil production of interspecific hybrids progenies between American oil palm, of 'Manicoré' origin, and oil palm, of 'La Mé' origin. Thirty-nine progenies were evaluated from the sixth to the ninth year after planting, for the productivity of fresh fruit bunches (PROD_FFB), oil content in the bunch (OCB), and palm oil productivity (PROD_OP). The genetic parameters and gains from direct (GDS) and indirect (GIS) selection were estimated for PROD_OP. High values of heritability for the $\mathrm{CVg} / \mathrm{CVe}$ ratio indicated favorable conditions for the selection. With the selection of $20 \%$ of the progenies (selection in both sexes), the following estimates were obtained: $11.15 \%$ GDS for PROD_OP, 9.1\% GIS for OCB, and 8.1\% GIS for PROD_FFB. The PROD_OP of the progenies was of 6,175, 6,057, and 5,995 $\mathrm{kg} \mathrm{ha}^{-1}$ per year with GDS and GIS for OCB and PROD_FFB, respectively. The restricted selection of the LM2T male genitor offspring resulted in $5.1 \%$ estimated GSD and in a mean of 5,800 $\mathrm{kg} \mathrm{ha}^{-1}$ per year for PROD_OP. Selection gains for PROD_OP can be achieved immediately through the selection restricted to oil palm male genitors, and, in the medium and long term, through the interspecific reciprocal recurrent selection between American oil palm and oil palm populations.
\end{abstract}

Index terms: Elaeis guineensis, Elaeis oleifera, genetic breeding, interspecific hybridization, selection strategies.

\section{Ganhos de seleção para a produção de óleo de palma em progênies de caiaué com dendê}

Resumo - O objetivo deste trabalho foi estimar os parâmetros genéticos, as correlações e os ganhos de seleção para a produção de óleo de progenies de híbridos interespecíficos entre caiaué, da origem 'Manicoré', e dendê da origem 'La Mé'. Trinta e nove progênies foram avaliadas, do sexto ao nono ano pósplantio, quanto a produtividade de cachos de frutos frescos (PROD_FFB), teor de óleo no cacho (OCB) e produtividade de óleo de palma (PROD_OP). Foram estimados os parâmetros genéticos e os ganhos de seleção direta (GDS) e indireta (GIS) para PROD_OP. Altos valores de herdabilidade para a razão $\mathrm{CVg} / \mathrm{CVe}$ indicaram condições favoráveis para a seleção. Com a seleção de $20 \%$ das progênies (seleção em ambos os sexos), as seguintes estimativas foram obtidas: 11,15\% de GDS para PROD_OP, 9,1\% GIS para OCB e 8,1\% GIS para PROD_FFB, respectivamente. A PROD_OP das progênies foi de 6.175, $6.057 \mathrm{e}$ $5.995 \mathrm{~kg} \mathrm{ha}^{-1}$ por ano, com GSD e GSI em OCB e PROD CFF, respectivamente. A seleção restrita a genitores masculinos de dendê LM2T resultou em 5,1\% de GSD e na média de $5.800 \mathrm{~kg} \mathrm{ha}^{-1}$ por ano para PROD_OP. Ganhos de seleção para PROD_OP podem ser obtidos imediatamente pela seleção restrita de genitores masculinos de dendê e, em médio e longo prazo, pela seleção recorrente recíproca interespecífica entre as populações de caiaué e dendê.

Termos para indexação: Elaeis guineensis, Elaeis oleifera, melhoramento genético, hibridação interespecífica, estratégias de seleção. 


\section{Introduction}

Palm oil extracted from the mesocarp (pulp) of the oil palm fruit (Elaeis guineensis Jacq.) is the most produced and commercialized vegetable oil in the world (USDA, 2021). This rank is the result of the high productivity of the crop that is the highest among oilseeds, and the low cost of oil production (OECDFAO..., 2019). Because of these advantages, palm oil is expected to supply most of the growing international demand for vegetable oil (Alain, 2020).

The sustainable expansion of palm oil in the country requires the development of cultivars adapted to local conditions and that are mainly of high productivity and resistance to pests and diseases (Cunha et al., 2012). In the 1980s, Embrapa started the interspecific genetic improvement of oil palm (E. guineensis) with American oil palm (Elaeis oleifera (HBK) Cortés), a species native to Central and South America (Cunha et al., 2012). The interspecific hybridization between American oil palm and oil palm (ISH OxG) has been exploited mainly for the resistance of the American species and F1 hybrids to bud rot, a disorder of undefined etiology that has extinguished thousands of hectares of oil palm plantations in Latin America, including Brazil. The HIE OxG hybrid also shows less vertical growth of the stem (Gomes Junior et al., 2015), besides resistance to other pests and diseases, and a more unsaturated oil than the palm oil (Cunha et al., 2012). In South America, Brazil and Colombia conduct the principal genetic improvement programs using the interspecific hybridization between American oil palm and oil palm (Rey B. et al., 2004; Bastidas et al., 2007; Cunha et al., 2012).

In 2010, Embrapa launched the first ISH OxG cultivar developed in Brazil, denominated 'BRS Manicoré', which shows bunch and oil productivity similar to that of the tenera-type oil palm cultivars, which already have at least five decades of genetic improvement (Cunha \& Lopes, 2010). 'BRS Manicoré' was obtained by combining the populations of 'Manicoré'-originated American oil palm and 'La Mé'-originated oil palms, in which there is still a high genetic variability to be explored. This fact allows of the prediction of high genetic gains with the continuity of interspecific improvement between these populations, including the obtention of more productive interspecific cultivars than the teneras of African oil palms (Lopes et al., 2012; Gomes Jr et al., 2014; Gomes Junior et al., 2015,
2016, 2019). The selection provided gains from distinct oil palm populations (Bakoumé \& Louise, 2007; Bakoumé et al., 2010; Noh et al., 2012) and should also be effective for breeding of HIE OxG hybrids.

The parameters of genetic variance and genetic gains for bunch production, vegetative characters and components of bunch have already been estimated from interspecific progenies obtained from populations between 'Manicoré'-originated American oil palm and 'La Mé"-originated oil palm (Gomes Jr. et al., 2014; Gomes Junior et al., 2015, 2016, 2019; Freitas et al., 2021). However, the principal economic product of oil palm plantation is the palm oil, so estimates of genetic gain for oil productivity are important for the continuity of interspecific genetic improvement using these populations.

The objective of this work was to estimate the genetic parameters, correlations, and selection gains for the oil production of interspecific hybrids progenies between American oil palm, of 'Manicoré' origin, and oil palm, of 'La Mé' origin.

\section{Materials and Methods}

Three experiments were set up in February 2007, in a continuous area of 17.6 ha, at the company Marborges Agroindustry S.A., in the municipality of Mojú $\left(1^{\circ} 58^{\prime} 42^{\prime \prime} \mathrm{S}, 48^{\circ} 36^{\prime} 50^{\prime \prime} \mathrm{W}\right)$, in the state of Pará, Brazil. The soil type in the experimental area is a Latossolo Amarelo distrófico, according to the Brazilian system of soil classification (Santos et al., 2018), i.e., a Dystric Xanthic Ferralsol (IUSS Working Group WRB, 2015). According to the Köppen-Geiger's classification, the local climate is the Af type (Alvares et al., 2013), with $2,786 \mathrm{~mm}$ annual mean precipitation (2007 to 2016), with a greater concentration of rainfall in the first semester of the year. The region is classified as preferred for the cultivation of oil palm, according to the Agroecological Zoning for the Oil Palm Crop in the Deforested Areas of the Legal Amazon - ZAEDendê (Ramalho Filho et al., 2010).

The experiments consisted of 39 progenies of full siblings obtained from controlled crosses involving 32 'Manicoré'-originated American oil palm female genitors, from 18 different families, and 13 'La Mé'originated pisifera-type oil palm male genitors, seven of which were from three different families of LM10T progenies, and six were from four different families of 
LM2T progenies (Table 1). Two experiments included 14 progenies, and one involved 15 progenies, with two progenies common to the three experiments (RUB 1195 and RUB 1213). The populations of the American oil palm and oil palm genitors are maintained in the Rio Urubu Experimental Field (CERU), Rio Preto da
Eva, state of Amazonas, Brazil, and they are used in the production of commercial seed of the 'BRS Manicoré' cultivar (RNC 26031).

The three experiments were established in a randomized complete block design, with four replicates, and 12 plants per plot (four lines of three

Table 1. Genealogy of $39 \mathrm{~F} 1$ progenies from crosses between female genitors of 'Manicoré'-originated American oil palm and male genitors of 'La Mé'-originated oil palms.

\begin{tabular}{|c|c|c|c|c|c|c|}
\hline \multirow[t]{2}{*}{ Progeny } & \multicolumn{2}{|c|}{ American oil palm (female parent) } & \multicolumn{3}{|c|}{ Oil palm (male parent) } & \multirow[t]{2}{*}{ Trial } \\
\hline & Family & Parent & Origin & Family & Parent & \\
\hline RUB 1198 & RUC 107 & RU $2842 \mathrm{D}$ & LM 2T & LM 12437 & RU 2707 P & 3 \\
\hline RUB 1226 & RUC 102 & RU 78 D & LM 2T & LM 12785 & RU 53 P & 1 \\
\hline RUB 1271 & RUC 224 & RU $1578 \mathrm{D}$ & LM $2 \mathrm{~T}$ & LM 13582 & RU $2691 \mathrm{P}$ & 1 \\
\hline RUB 1210 & RUC 76 & RU 3308 D & LM 2T & LM 13582 & RU $2691 \mathrm{P}$ & 2 \\
\hline RUB 1227 & RUC 102 & RU 2846 D & LM 2T & LM 13582 & RU $2692 \mathrm{P}$ & 1 \\
\hline RUB 1283 & RUC 103 & RU 92 D & LM $2 \mathrm{~T}$ & LM 13582 & RU $2692 \mathrm{P}$ & 1 \\
\hline RUB 1196 & RUC 107 & RU $2841 \mathrm{D}$ & LM 2T & LM 13582 & RU $2692 \mathrm{P}$ & 3 \\
\hline RUB 1274 & RUC 224 & RU $1578 \mathrm{D}$ & LM 2T & LM 13582 & RU $2692 \mathrm{P}$ & 1 \\
\hline RUB 1199 & RUC 109 & RU 3099 D & LM $2 \mathrm{~T}$ & LM 13582 & RU 2693 P & 3 \\
\hline RUB 1211 & RUC 76 & RU $3111 \mathrm{D}$ & LM $2 \mathrm{~T}$ & LM 13582 & RU 2693 P & 2 \\
\hline RUB 1218 & RUC 79 & RU 2900 D & LM 2T & LM 13582 & RU 2693 P & 2 \\
\hline RUB 1219 & RUC 79 & RU $2901 \mathrm{D}$ & LM 2T & LM 13582 & RU 2693 P & 2 \\
\hline RUB 1208 & RUC 80 & RU $2905 \mathrm{D}$ & LM $2 \mathrm{~T}$ & LM 13582 & RU 2693 P & 3 \\
\hline RUB 1232 & RUC 104 & RU 3079 D & LM $2 \mathrm{~T}$ & LM 13582 & RU 2749 P & 1 \\
\hline RUB 1202 & RUC 93 & RU 1608 D & LM 2T & LM 13582 & RU 2749 P & 3 \\
\hline RUB 1234 & RUC 105 & RU 3189 D & LM $10 \mathrm{~T}$ & LM 12011 & RU 2710 P & 1 \\
\hline RUB 1201 & RUC 109 & RU 3089 D & LM $10 \mathrm{~T}$ & LM 12011 & RU 2710 P & 3 \\
\hline RUB 1221 & RUC 114 & RU $101 \mathrm{D}$ & LM $10 \mathrm{~T}$ & LM 12011 & RU 2710 P & 2 \\
\hline RUB 1223 & RUC 224 & RU 1578 D & LM $10 \mathrm{~T}$ & LM 12011 & RU 2710 P & 2 \\
\hline RUB 1213 & RUC 76 & RU 1724 D & LM $10 \mathrm{~T}$ & LM 12011 & RU $2710 \mathrm{P}$ & 1,2 , and 3 \\
\hline RUB 1204 & RUC 96 & RU 3170 D & LM 10T & LM 12011 & RU 2710 P & 3 \\
\hline RUB 1225 & RUC 102 & RU 2839 D & LM $10 \mathrm{~T}$ & LM 12011 & RU 56 P & 1 \\
\hline RUB 1231 & RUC 103 & RU 92 D & LM $10 \mathrm{~T}$ & LM 12011 & RU 56 P & 1 \\
\hline RUB 1233 & RUC 104 & RU $3101 \mathrm{D}$ & LM $10 \mathrm{~T}$ & LM 12011 & RU 56 P & 1 \\
\hline RUB 1195 & RUC 107 & RU 1604 D & LM $10 \mathrm{~T}$ & LM 12011 & RU 56 P & 1,2 , and 3 \\
\hline RUB 1203 & RUC 95 & RU 1778 D & LM $10 \mathrm{~T}$ & LM 12252 & RU $2698 \mathrm{P}$ & 3 \\
\hline RUB 1212 & RUC 76 & RU $3111 \mathrm{D}$ & LM $10 \mathrm{~T}$ & LM 12252 & RU $2700 \mathrm{P}$ & 2 \\
\hline RUB 1214 & RUC 77 & RU 2914 D & LM $10 \mathrm{~T}$ & LM 12252 & RU $2700 \mathrm{P}$ & 2 \\
\hline RUB 1215 & RUC 78 & RU 3359 D & LM $10 \mathrm{~T}$ & LM 12252 & RU $2700 \mathrm{P}$ & 2 \\
\hline RUB 1205 & RUC 96 & RU 3123 D & LM $10 \mathrm{~T}$ & LM 12252 & RU $2700 \mathrm{P}$ & 3 \\
\hline RUB 1206 & RUC 96 & RU 3169 D & LM $10 \mathrm{~T}$ & LM 12252 & RU $2700 \mathrm{P}$ & 3 \\
\hline RUB 1209 & RUC 43 & RU $2787 \mathrm{D}$ & LM 10T & LM 12252 & RU 2733 P & 2 \\
\hline RUB 1224 & RUC 102 & RU 2845 D & LM $10 \mathrm{~T}$ & LM 13751 & RU 2729 P & 2 \\
\hline RUB 1197 & RUC 107 & RU 2842 D & LM $10 \mathrm{~T}$ & LM 13751 & RU $2730 \mathrm{P}$ & 3 \\
\hline RUB 1200 & RUC 109 & RU 3089 D & LM $10 \mathrm{~T}$ & LM 13751 & RU 2730 P & 3 \\
\hline RUB 1217 & RUC 224 & RU 1578 D & LM $10 \mathrm{~T}$ & LM 13751 & RU $2730 \mathrm{P}$ & 2 \\
\hline RUB 1220 & RUC 79 & RU $1588 \mathrm{D}$ & LM $10 \mathrm{~T}$ & LM 13751 & RU $2730 \mathrm{P}$ & 2 \\
\hline RUB 1277 & RUC 79 & RU 1586 D & LM $10 \mathrm{~T}$ & LM 13751 & RU $2730 \mathrm{P}$ & 1 \\
\hline RUB 1250 & RUC 97 & RU 1605 D & LM $10 \mathrm{~T}$ & LM 13751 & RU 2730 P & 1 \\
\hline
\end{tabular}


plants). As a border, a line was used at each side of the experimental area, with a plant at each end of the lines of the experiment. The planting was performed at 143 plants ha ${ }^{-1}$ and conducted according to the management practices adapted by the company Marborges S.A. (Pina, 2010). The assisted pollination practice is the main differential in relation to the production system of the oil palm cropping.

Bunch production was evaluated in the adult phase of the plants, at intervals between 15 and 20 days, for four consecutive years, from January 2013 (sixth year after planting) to December 2016 (ninth year after planting). The values of the fresh fruit bunch production (FFB) from plots were transformed into productivity, considering the planting density adopted in the experiment, and they were expressed in productivity $\left(\mathrm{Mg} \mathrm{ha}^{-1}\right.$ per year) of fresh fruit bunch (PROD_FFB). The oil content in the bunch (OCB) was obtained by means of physical analysis of the bunches and chemical extraction (Soxhlet) of palm oil from the mesocarp, following the methodology adapted from the proposal of the Nigerian Institute for Palm Oil Research (Black et al., 1963; Rao et al., 1983). The average of 55 bunches per progeny harvested in 2015, 2016, and 2017 were analyzed. In the physical analysis of the bunches, the spikelets with fruit and rachis of the bunches were first separated and weighed. To determine the proportion of fruit on the bunch weight and the oil content, bunches weighing less than 14 $\mathrm{kg}$ were used with all spikelets, whereas in the cases with bunch weight greater than this value, half of the spikelets was used. Fruit were manually removed from the spikelets, classified as normal and parthenocarpic and, then, they were weighed. A sample with 30 normal fruit and 30 parthenocarpic fruit was randomly selected from each bunch and used to calculate the proportion of mesocarp in the weight of the fruit. The mesocarp was manually extracted from the fruit with the aid of a stainless-steel knife, then the weight of the mesocarp and the weight of the kernel almonds in the sample were obtained. Fresh mesocarps were dried at $105^{\circ} \mathrm{C}$ for 24 hours, in an oven with air circulation and renewal (model TE-394, Tecnal, SP, Brazil). After the drying time, the mesocarps were cooled in a desiccator, at room temperature, and then weighed and crushed in a domestic processor (model LN 73, Arno, SP, Brazil), until a particle size of approximately $2.0 \mathrm{~mm}$ was obtained. The extraction of lipids from the mesocarps was performed in a $5 \mathrm{~g}$ sample of dry mesocarp, in a
Soxhlet system, using petroleum ether as solvent. The analyses were carried out at the laboratory of Embrapa Amazônia Oriental Agroindústria.

The oil content in the bunch (OCB) (Equation 1), expressed as a percentage of the weight of fresh fruit bunches (FFB), was determined by the sum between the percentage of lipids over the FFB weight of normal fruit (NF) and parthenocarpic fruit (PF) (Equation 2).

$\frac{\mathrm{O}}{\mathrm{FFB}}(\%)=\frac{\mathrm{O}_{\mathrm{NF}}}{\mathrm{FFB}}(\%)+\frac{\mathrm{O}_{\mathrm{PF}}}{\mathrm{FFB}}(\%)$

$\frac{\mathrm{O}_{\mathrm{NF} \text { or PF }}}{\text { FFB }}(\%)=\frac{1}{10.000}\left[\left(\frac{\mathrm{NF} \text { ou PF }}{\text { FFB }}(\%)\right)\left(\frac{\mathrm{M}}{\mathrm{NF} \text { or PF }}(\%)\right)\left(\frac{\mathrm{o}}{\mathrm{M}_{\mathrm{NF} \text { or PF }}}(\%)\right)\right]$

in which: NF or PF/FFB (\%) is the percentage of NF or $\mathrm{PF}$ in $\mathrm{FFB}$ (equation 3); $\mathrm{M} / \mathrm{NF}$ or $\mathrm{PF}(\%)$ is the mesocarp (M) pencentage in NF or PF (equation 4); $\mathrm{O} / \mathrm{M} \mathrm{NF}$ or PF (\%) is the oil percentage in the NF or PF mesocarp (equation 5).

$\frac{\text { NF or PF }}{\text { FFB }}(\%)=100\left[\left(\frac{\text { NF or PF }}{\text { SWF }}\right)\left(\frac{\text { FFB }-R}{\text { FFB }}\right)\right]$

in which: SWF represents spikelets with fruit, and R represents the rachis.

$$
\begin{aligned}
& \frac{\mathrm{M}}{\mathrm{NF} \text { or } \mathrm{PF}}(\%)=100\left(\frac{(\mathrm{NF} \text { or PF })-\text { kernell }}{(\mathrm{NF} \text { or PF })}\right) \\
& \frac{\mathrm{o}}{\mathrm{M}_{\mathrm{NF} \text { or } P F}}(\%)=\frac{1}{100}\left[\left(100-\mathrm{MM}_{\mathrm{NF} \text { or } P F}(\%)\right)\left(\frac{\mathrm{o}}{\mathrm{M}_{\mathrm{NF} \text { or } P F(\mathrm{dry})}}(\%)\right)\right]
\end{aligned}
$$

in which: MM is the mesocarp moisture.

From the direct product of PROD_FFB and OCB, the palm oil productivity (PROD_OP) ( $\mathrm{kg}$ of palm oil ha $\mathrm{h}^{-1}$ per year) was calculated. The gains in palm oil productivity, estimated with the extraction rate obtained in the laboratory, were also expressed in expected values at the level of industrial extraction, using the mean value for industrial efficiency of $93.1 \%$ as a reference, that is the mean value reported for industries used as benchmarking (optimal processing parameters) in a study developed with the Malaysian Palm Oil Board (Menon, 2012).

The results of the three experiments were subjected to the analysis of grouped variance, with the adjustment of the mean of the progenies. Genetic parameters, genetic correlations, and direct and indirect selection gains were estimated in an aleatory model (Cruz, 2006a), using the Genes software (Cruz, 2006b), 
for the characteristics PROD_FFB, PROD_OP, and OCB. In the analysis of grouped variance of the three experiments, the values $\mathrm{Z}$ and $\mathrm{Y}$ were used to refer to the same variable, and to represent the values of common and regular progenies, respectively, as follows:

$\mathrm{Z}_{\mathrm{ijk}}=\mu+\mathrm{Tc}_{\mathrm{i}}+\mathrm{B}_{\mathrm{j}(\mathrm{k})}+\mathrm{E}_{\mathrm{k}}+\mathrm{TcE}_{\mathrm{ik}}+\varepsilon_{\mathrm{ijk}}$

in which: $Z_{\mathrm{ijk}}$ is the observation under the $\mathrm{i}^{\text {th }}$ common progeny, in the $\mathrm{j}^{\text {th }}$ block, in the $\mathrm{k}^{\text {th }}$ experiment; $\mu$ is the experimental average; $\mathrm{Tc}_{\mathrm{i}}$ is the $\mathrm{i}^{\text {th }}$ common progeny effect; $B_{j(k)}$ is the effect of $j^{\text {th }}$ block, within $k^{\text {th }}$ experiment; $\mathrm{E}_{\mathrm{k}}$ is the $\mathrm{k}^{\text {th }}$ experiment effect; $\mathrm{Tc}_{\mathrm{ik}}$ is the interaction effect of $i^{\text {th }}$ common progeny $x$, in thte $\mathrm{k}^{\text {th }}$ experiment; $\varepsilon_{\mathrm{ijk}}$ is the aleatory error.

$$
\mathrm{Y}_{\mathrm{ijk}}=\mu+\operatorname{Tr}_{\mathrm{i}}+\mathrm{B}_{\mathrm{j}}+\varepsilon_{\mathrm{ij}(\mathrm{k})}
$$

in which: $Y_{\mathrm{ijk}}$ is the observation under the $\mathrm{i}^{\text {th }}$ regular progeny, in the $\mathrm{j}^{\text {th }}$ block, in the $\mathrm{k}^{\text {th }}$ experiment; $\mu$ is the experimental average; $\operatorname{Tr}_{\mathrm{i}}$ is the $\mathrm{i}^{\text {th }}$ regular progeny effect; $B_{j}$ is the effect of the $j^{\text {th }}$ block, at the $\mathrm{k}^{\text {th }}$ experiment; $\varepsilon_{\mathrm{ijk}}$ is the aleatory error.

The genetic selection gain was estimated considering the selection of the best $20 \%$ classified progenies (eight progenies) for selection in both parent populations, female genitors of 'Manicoré'originated American oil palm, and male genitors of 'La Mé'-originated oil palm. In the case of selection restricted to male population, the select genetic gain was estimated considering the higher progenies mean among LM2T and LM10T genitors. The genetic gain from direct selection (GDS) was estimated by GDS $=\mathrm{h}$ ${ }_{\mathrm{m}}^{2} \times \mathrm{SD}$ and GDS $(\%)=100 \times \mathrm{GDS} / \overline{\mathrm{X}}_{\mathrm{o}}$, in which: $\mathrm{h}_{\mathrm{m}}^{2}$ is the heritability at progeny mean level, estimated from the matrices of genotypic and phenotypic variances and covariances among progeny means; $\mathrm{SD}=\overline{\mathrm{X}}_{\mathrm{s}}-\overline{\mathrm{X}}_{\mathrm{o}}$ is the selection differential, where $\bar{X}_{o}$ is the overall adjusted mean; and $\bar{X}_{s}$ is the adjusted mean of the selected progenies. Estimates for indirect genetic gain (GIS) was calculated by $\mathrm{GIS}_{\mathrm{j}(\mathrm{i})}=\mathrm{h}_{\mathrm{m}(\mathrm{j})}^{2} \mathrm{x} \mathrm{SD}_{\mathrm{j}(\mathrm{i})}$, in which GIS $_{\mathrm{j}(\mathrm{i})}$ is the indirect gain selection on characteristics $\mathrm{j}$, by selection on characteristics $\mathrm{i} ; \mathrm{SD}_{\mathrm{j}(\mathrm{i})}=\overline{\mathrm{X}}_{\mathrm{Sj}}-\overline{\mathrm{X}}_{\mathrm{Oj}}$ is the indirect selection differential, where $\bar{X}_{\text {oj }}$ is the overall adjusted mean of characteristics $\mathrm{j}$; and $\overline{\mathrm{X}}_{\mathrm{Sj}}$ is the adjusted mean of characteristics $\mathrm{j}$ of the selected progenies on characteristics $i$. The indirect selection efficiency was calculated by ISE $=\mathrm{GIS}_{\mathrm{j}(\mathrm{i})} / \mathrm{GDS}_{\mathrm{j}}$.

The genetic correlations $\left(\mathrm{r}_{\mathrm{g}}\right)$ between characteristics $\mathrm{x}$ and $\mathrm{y}$ were estimated by $\mathrm{r}_{\mathrm{g}}=\mathrm{COVg}(\mathrm{xy}) / \sqrt{ } \operatorname{Vg}(\mathrm{x}) \times \operatorname{Vg}(\mathrm{y})$, in which: $\operatorname{COVg}(\mathrm{xy})$ is the covariance of the genotypic characteristics $x$ and characteristics $y ; \operatorname{Vg}(x)$ and $\operatorname{Vg}(y)$ are the variances of the genotypic characteristics $\mathrm{x}$ and characteristics y, respectively.

\section{Results and discussion}

The coefficients of experimental variation (CV\%) for all traits were low, following the classification by Pimentel-Gomes (2009), which indicates the high precision of the experiment (Table 2). Out of the 2,030 useful plants of the experiments, only $34(1.68 \%$ lost data) were excluded from the analysis, due to dead, or abnormal development, that is a low percentage of lost data for a 9-year experiment. The results can be attributed to the good crop management adopted during the research and the environmental favorable conditions for oil palm cultivation. The percentage of dead plants was lower than that observed in hybrids of the same origin cultivated in the municipality of Una, in the state of Bahia, Brazil, where eight years after planting there were $4 \%$ loss of plants due to death, mainly due to red ring disease (Pinto et al., 2019). The grouped variance analysis indicated a significant effect with high $\mathrm{F}$ values of the adjusted mean of the progenies for palm oil productivity (PROD_OP), fresh fruit bunch productivity (PROD_FFB), and palm oil content in the fresh fruit bunch (OCB).

The estimates of the genetic parameters indicated favorable conditions for selection with the possibility of genetic gain for PROD_OP and for the other evaluated characteristics (Table 2). The estimated heritability at the level of mean of progenies was high, which reflects the predominance of the variance of genetic origin over the environmental variance. In the same sense, the $\mathrm{CVg} / \mathrm{CVe}$ relation also indicated that the genetic variance exceeded the environmental one. Similar results for HIE OxG evaluated for PROD_FFB were observed (Lopes et al., 2012; Gomes Jr et al., 2014; Gomes Junior et al., 2015, 2016), and for OCB by Freitas et al. (2021).

The means of the progenies for PROD_FFB (Table 3) were great than the means values observed for FFB_PROD by Amiruddin et al. (2015) in ISH 
OxG progenies evaluated in four different locations in Malaysia, which were from 12.7 to $28.9 \mathrm{Mg} \mathrm{ha}^{-1}$ per year (estimated values from PROD_FFB $\mathrm{kg}_{\text {plant }}{ }^{-1}$ per year presented by the authors, considering the planting density of 143 plants ha $\left.{ }^{-1}\right)$. When considering the industrial extraction efficiency (IEE) of 93.1\%, the mean of progenies for PROD_OP variated from 3,987 to $6,580 \mathrm{~kg} \mathrm{ha}^{-1}$ per year, and for OCB, from 18.4 to $23.3 \%$. Lower mean values for OCB in ISH $\mathrm{OxG}$ than those registered in the present work were observed by Mandal et al. (2009) and Amiruddin et al. (2015). According to Woittiez et al. (2017), the average productivity of palm oil at the international level, in the 2013 harvest, was from 3.0 to $3.2 \mathrm{Mg} \mathrm{ha}^{-1}$ per year, and the productivity in Indonesia, the world's largest producer, was estimated as $3.8 \mathrm{Mg} \mathrm{ha}^{-1}$ per year. In Malaysia, the second largest world's producer and technological reference, it was between 4.2 to $4.5 \mathrm{Mgt}$ $\mathrm{ha}^{-1}$ per year, and in Brazil, between 2.8 to $3.1 \mathrm{Mg} \mathrm{ha}^{-1}$ per year. The observed values for PROD_OP are high and indicate a great potential for interspecific hybrids improvement between the female genitors 'Manicoré"originated American oil palm and the male genitors 'La Mé'-originated of oil palm.

High values of genetic correlation were found between PROD_OP and PROD_FFB and between PROD_OP and OCB, which indicates that the increases of PROD_FFB and OCB will result in greater PROD OP (Table 4). In addition, the low correlation between PROD_FFB and OCB indicates a nonsignificant impact of selecting one characteristic on the variation of the other. Krualee et al. (2013) identified in dura $\mathrm{x}$ pisifera oil palm progenies positive genotypic and phenotypic correlation coefficient values between PROD_FFB and PROD_OP, while Rios et al. (2018) verified a high and positive phenotypic correlation between FFB_PROD and PRO_PO in half sibs of dura-type oil palm progenies.

The direct genetic selection (GDS) in PROD_OP was high, with the selection of $20 \%$ of the progenies with the best performance, which represents $11.2 \%$ over the mean of the original population (Table 5). When considering the demand for 11 years of experimentation, from the crossing to the conclusion of the progeny evaluation, GDS was estimated at approximately $1 \%$ per year for PROD_OP. The genetic improvement of oil palm yield started in the 1920s through the mass selection, and the genetic progress of PROD_OP for the best breeding programs around the world is about 1 to $1.5 \%$ per year (Nyouma et al., 2019).

The GIS in PROD_OP indicated a greater efficiency of indirect selection for OCB (81.1\% of GSD) than for PROD_FFB $(72.7 \%$ GSD). The genetic progress in PROD_OP via indirect selection in OCB and PROD_

Table 2. Analysis of grouped variance and estimates of genetic parameters for the variables palm oil productivity (PROD OP), productivity of fresh fruit bunch (PROD_FFB), and content of palm oil in the fresh fruit bunch (OCB), evaluated from the $6^{\text {th }}$ to the $9^{\text {th }}$ years after planting, in 39 F1progenies from crosses between female genitors of 'Manicoré'-originated American oil palm and male genitors of 'La Mé'-originated oil palms.

\begin{tabular}{|c|c|c|c|c|c|c|c|}
\hline \multirow[t]{3}{*}{ Source of variation } & \multirow[t]{3}{*}{ DF } & \multicolumn{6}{|c|}{ Mean Square } \\
\hline & & \multicolumn{2}{|c|}{ PROD_OP $\left(\mathrm{kg} \mathrm{ha}^{-1}\right.$ per year $)$} & \multicolumn{2}{|c|}{ PROD_FFB (Mg ha ${ }^{-1}$ per year) } & \multicolumn{2}{|c|}{ OCB $(\%)$} \\
\hline & & QM & $\mathrm{F}$ & $\mathrm{QM}$ & $\mathrm{F}$ & QM & $\mathrm{F}$ \\
\hline Replicates & 9 & 139,174 & & 3.66 & & 0.74 & \\
\hline Trials & 2 & $7,908,881$ & $48.0 * *$ & 92.3 & $30.9 * *$ & 11.9 & $11.9 * *$ \\
\hline Common trat. $\mathrm{x}$ Trials & 2 & 249,321 & $1.5^{\mathrm{ns}}$ & 3.69 & $1.2^{\mathrm{ns}}$ & 0.49 & $0.5^{\text {ns }}$ \\
\hline Adjusted treatments & 38 & $1,235,461$ & $7.5^{* *}$ & 15.5 & $5.2 * *$ & 7.03 & $7.0^{* *}$ \\
\hline Residual & 120 & 164,622 & & 2.99 & & 1.00 & \\
\hline Means $^{(1)}$ & & 5,429 & $(4,615)$ & 25.2 & $(23.5)$ & 21.5 & $(18.3)$ \\
\hline CV (\%) & & 7.47 & & 5.62 & & 4.65 & \\
\hline Genotypic variance (mean) & & 267,709 & & 3.38 & & 1.51 & \\
\hline Heritability (\%) & & 86.7 & & 87.1 & & 85.7 & \\
\hline Intraclass correlation (\%) & & 61.9 & & 62.9 & & 60.0 & \\
\hline $\operatorname{CVg}(\%)$ & & 9.43 & & 7.23 & & 5.70 & \\
\hline $\mathrm{CVg} / \mathrm{Cve}$ & & 1.26 & & 1.29 & & 1.23 & \\
\hline
\end{tabular}

${ }^{(1)}$ The estimates of population mean of PROD_OP and OCB are shown in the absolute scale and in values with $93.1 \%$ adjustment (in parentheses), referring to the benchmarking for the industrial efficiency of palm oil extraction (Menon, 2012). **Significant at $1 \%$ probability by the $\mathrm{F}$ test. 
Tabela 3. Palm oil productivity (PROD_OP), productivity of fresh fruit bunch (PROD_FFB), and palm oil content in the fresh fruit bunch $(\mathrm{OCB})$, evaluated from the $6^{\text {th }}$ to the $9^{\text {th }}$ year after planting, in 39 F1progenies from crosses between female genitors of 'Manicoré'-originated American oil palm and male genitors of 'La Mé'-originated oil palms.

\begin{tabular}{|c|c|c|c|c|c|c|c|}
\hline \multirow{2}{*}{ Progeny } & \multirow{2}{*}{ Male origin } & \multicolumn{2}{|c|}{ PROD_OP } & \multicolumn{2}{|c|}{ PROD_FFB } & \multicolumn{2}{|c|}{$\mathrm{OCB}$} \\
\hline & & (kg ha $^{-1}$ per year) & Rank & $\left(\mathrm{Mg} \mathrm{ha}^{-1}\right.$ per year) & Rank & $(\%)$ & Rank \\
\hline RUB 1199 & LM 2T & $7,068(6,580)$ & 1 & 29.4 & 1 & $23.8(22.16)$ & 3 \\
\hline RUB 1218 & LM $2 \mathrm{~T}$ & $6,293(5,858)$ & 2 & 27.9 & 4 & $22.5(20.9)$ & 7 \\
\hline RUB 1211 & LM $2 \mathrm{~T}$ & $6,263(5,830)$ & 3 & 25.0 & 26 & $25.0(23.3)$ & 1 \\
\hline RUB 1250 & LM 10T & $6,120(5,697)$ & 4 & 26.0 & 15 & $23.7(22.1)$ & 4 \\
\hline RUB 1198 & LM $2 \mathrm{~T}$ & $5,997(5,583)$ & 5 & 28.2 & 2 & $21.2(19.7)$ & 23 \\
\hline RUB 1196 & LM $2 \mathrm{~T}$ & $5,970(5,558)$ & 6 & 26.5 & 9 & $22.4(20.9)$ & 8 \\
\hline RUB 1227 & LM $2 \mathrm{~T}$ & $5,962(5,550)$ & 7 & 26.4 & 10 & $22.7(21.1)$ & 6 \\
\hline RUB 1215 & LM 10T & $5,889(5,482)$ & 8 & 27.7 & 5 & $21.2(19.7)$ & 22 \\
\hline RUB 1210 & LM 2T & $5,883(5,477)$ & 9 & 26.6 & 8 & $22.0(20.5)$ & 13 \\
\hline RUB 1209 & LM 10T & $5,698(5,304)$ & 10 & 28.1 & 3 & $20.2(18.8)$ & 33 \\
\hline RUB 1274 & LM $2 \mathrm{~T}$ & $5,676(5,284)$ & 11 & 25.6 & 21 & $22.2(20.7)$ & 11 \\
\hline RUB 1212 & LM 10T & $5,648(5,258)$ & 12 & 27.0 & 7 & $20.9(19.5)$ & 27 \\
\hline RUB 1217 & LM 10T & $5,645(5,255)$ & 13 & 25.8 & 17 & $21.8(20.3)$ & 16 \\
\hline RUB 1208 & LM 2T & $5,625(5,236)$ & 14 & 23.1 & 35 & $24.2(22.5)$ & 2 \\
\hline RUB 1283 & LM $2 \mathrm{~T}$ & $5,610(5,222)$ & 15 & 26.0 & 16 & $21.7(20.2)$ & 18 \\
\hline RUB 1226 & LM $2 \mathrm{~T}$ & $5,559(5,175)$ & 16 & 26.4 & 11 & $21.1(19.6)$ & 25 \\
\hline RUB 1220 & LM 10T & $5,545(5,162)$ & 17 & 25.0 & 25 & $22.2(20.7)$ & 12 \\
\hline RUB 1200 & LM 10T & $5,495(5,115)$ & 18 & 26.1 & 14 & $21.0(19.6)$ & 26 \\
\hline RUB 1271 & LM 2T & $5,493(5,113)$ & 19 & 25.8 & 19 & $21.4(19.9)$ & 21 \\
\hline RUB 1205 & LM 10T & $5,483(5,104)$ & 20 & 27.6 & 6 & $19.9(18.5)$ & 37 \\
\hline RUB 1231 & LM 10T & $5,456(5,079)$ & 21 & 26.3 & 12 & $20.8(19.5)$ & 28 \\
\hline RUB 1195 & LM 10T & $5,439(5,063)$ & 22 & 24.9 & 27 & $21.9(20.4)$ & 14 \\
\hline RUB 1225 & LM 10T & $5,409(5,035)$ & 23 & 25.2 & 24 & $21.5(20.0)$ & 19 \\
\hline RUB 1219 & LM $2 \mathrm{~T}$ & $5,352(4,982)$ & 24 & 25.3 & 22 & $21.2(19.7)$ & 24 \\
\hline RUB 1206 & LM 10T & $5,297(4,931)$ & 25 & 26.1 & 13 & $20.2(18.8)$ & 32 \\
\hline RUB 1197 & LM 10T & $5,292(4,926)$ & 26 & 25.7 & 20 & $20.6(19.2)$ & 31 \\
\hline RUB 1232 & LM $2 \mathrm{~T}$ & $5,200(4,841)$ & 27 & 23.9 & 29 & $21.8(20.3)$ & 17 \\
\hline RUB 1277 & LM 10T & $5,158(4,802)$ & 28 & 23.2 & 33 & $22.3(20.8)$ & 10 \\
\hline RUB 1204 & LM 10T & $5,154(4,798)$ & 29 & 22.4 & 36 & $23.0(21.4)$ & 5 \\
\hline RUB 1233 & LM $10 \mathrm{~T}$ & $5,129(4,775)$ & 30 & 23.5 & 32 & $21.9(20.4)$ & 15 \\
\hline RUB 1224 & LM 10T & $5,094(4,742)$ & 31 & 25.2 & 23 & $20.1(18.7)$ & 34 \\
\hline RUB 1202 & LM 2T & $5,052(4,703)$ & 32 & 24.4 & 28 & $20.7(19.3)$ & 30 \\
\hline RUB 1214 & LM 10T & $5,046(4,697)$ & 33 & 25.8 & 18 & $19.5(18.2)$ & 38 \\
\hline RUB 1203 & LM 10T & $5,022(4,675)$ & 34 & 22.3 & 37 & $22.4(20.9)$ & 9 \\
\hline RUB 1221 & LM 10T & $4,931(4,590)$ & 35 & 23.7 & 31 & $20.8(19.4)$ & 29 \\
\hline RUB 1213 & LM 10T & $4,758(4,429)$ & 36 & 22.2 & 38 & 21.4 (19.9) & 20 \\
\hline RUB 1223 & LM 10T & $4,639(4,318)$ & 37 & 23.2 & 34 & $20.1(18.7)$ & 36 \\
\hline RUB 1201 & LM 10T & $4,378(4,075)$ & 38 & 23.8 & 30 & $18.4(17.1)$ & 39 \\
\hline RUB 1234 & LM 10T & $4,283(3,987)$ & 39 & 21.2 & 39 & $20.1(18.7)$ & 35 \\
\hline Minimum & & $4,283(3,987)$ & & 21.2 & & $18.4(17.1)$ & \\
\hline Maximum & & $7,068(6,580)$ & & 29.4 & & $25.0(23.3)$ & \\
\hline Mean & & $5,462(5,085)$ & & 25.3 & & $21.5(20.0)$ & \\
\hline
\end{tabular}

The phenotypic values of the PROD PO and OCB are shown in the absolute scale and in values with $93.1 \%$ adjustment (in parentheses), referring to the benchmarking for the industrial efficiency of palm oil extraction (Menon, 2012). 
FFB was approximately 0.7 and $0.8 \%$ per year. Despite generating significant gains, up to $494 \mathrm{~kg} \mathrm{ha}^{-1}$ per year in PROD_OP, the indirect selection is not capable of obtaining gains compatible with the most successful oil

Table 4. Genotypic (top of the table) and phenotypic (bottom of the table) correlations between the variables palm oil productivity (PROD_OP), productivity of fresh fruit bunch (PROD_FFB) and oil content in the bunch (OCB), evaluated from the $6^{\text {th }}$ to the $9^{\text {th }}$ year after planting, in $39 \mathrm{~F} 1$ progenies, from crosses between female genitors of 'Manicoré'-originated American oil palm and male genitors of 'La Mé'-originated oil palms.

\begin{tabular}{lccc}
\hline Variable & PROD_OP & PROD_FFB & OCB \\
\hline PROD_OP & - & 0.761 & 0.683 \\
PROD_FFB & 0.764 & - & 0.050 \\
OCB & 0.680 & 0.051 & - \\
\hline
\end{tabular}

palm genetic improvement programs in the world. The estimates of improved population were 5,767, 5,639, and 5,581 $\mathrm{kg} \mathrm{ha}^{-1}$ per year, considering direct selection and indirect selection via OCB and via PROD_FFB, respectively.

Genetic gain estimates with the restrict selection of male genitors indicated the possibility of immediate gains for PROD_OP (Table 6). The restricted selection of male genitors LM $2 \mathrm{~T}$ progeny resulted in the estimated genetic gains for PROD_OP of 5,1\% of immediate gain over the mean of the original population. In the PROD_FFB evaluation, Gomes Junior et al. (2019) and Pinto et al. (2019) also observed the superiority of 'Manicoré' x LM2T progenies, in comparison with 'Manicoré' x LM10T progenies. From the results attained by the authors, it can be concluded that, on average, the capacity of combining LM2T oil

Table 5. Direct (GDS) and indirect (GIS) genetic selection gain estimates for palm oil productivity (PROD_OP), evaluated from the $6^{\text {th }}$ to the $9^{\text {th }}$ year after planting, in $39 \mathrm{~F} 1$ progenies, from crosses between female genitors of 'Manicoré'-originated American oil palm and male genitors of 'La Mé'-originated oil palms, with indirect selection based on the productivity of fresh fruit bunch (PROD_FFB), oil content in the fresh fruit bunch (OCB), and selection of 20\% of the progenies.

\begin{tabular}{|c|c|c|c|c|c|c|}
\hline \multirow{3}{*}{ Selected variable } & \multirow{3}{*}{ Selected progenies } & \multicolumn{5}{|c|}{ Response on PROD_OP } \\
\hline & & $\overline{\mathrm{X}}_{\mathrm{S}}$ & SD & SD & GS & ISE \\
\hline & & \multicolumn{3}{|c|}{----------(kg ha' ${ }^{-1}$ per year ${ }^{(1)}$} & \multicolumn{2}{|c|}{$(\%)$} \\
\hline PROD_OP & $\begin{array}{l}\text { RUB } 1199 \text { (LM 2T), RUB } 1218 \text { (LM 2T), RUB } 1211 \text { (LM 2T), } \\
\text { RUB } 1250 \text { (LM } 10 \text { T), RUB } 1198 \text { (LM 2T), RUB } 1196 \text { (LM 2T), } \\
\text { RUB } 1227 \text { (LM 2T) e RUB } 1215 \text { (LM 10T) }\end{array}$ & $6,195(5,767)$ & $733(682)$ & $609(566)$ & 11.2 & - \\
\hline PROD_FFB & $\begin{array}{l}\text { RUB } 1999 \text { (LM 2T), RUB } 1198 \text { (LM 2T), RUB } 1209 \text { (LM 10T), } \\
\text { RUB } 1218 \text { (LM 2T), RUB } 1215 \text { (LM 10T), RUB } 1205 \text { (LM } 10 \text { T), } \\
\text { RUB } 1212 \text { (LM 10 T) e RUB } 1210 \text { (LM 2T) }\end{array}$ & $5,995(5,581)$ & $533(496)$ & $442(411)$ & 8.10 & 72.7 \\
\hline $\mathrm{OCB}$ & $\begin{array}{l}\text { RUB } 1211 \text { (LM 2T), RUB } 1208 \text { (LM 2T), RUB } 1199 \text { (LM 2T), } \\
\text { RUB } 1250 \text { (LM } 10 \text { T), RUB } 1204 \text { (LM } 10 \text { T), RUB } 1227 \text { (LM } \\
\text { 2T), RUB } 1218 \text { (LM 2T) e RUB } 1196 \text { (LM 2T) }\end{array}$ & $6,057(5,639)$ & $595(553)$ & $494(456)$ & 9.10 & 81.1 \\
\hline
\end{tabular}

$\overline{\mathrm{X}}_{\mathrm{S}}$ estimates of mean of the selected progenies; SD, selection differential; and ISE, indirect selection efficiency. The genetic parameters $\overline{\mathrm{X}}_{\mathrm{S}}$, SD, and SG ( $\mathrm{kg} \mathrm{ha}^{-1}$ per year) are shown in the absolute scale and in values with $93.1 \%$ adjustment (in parentheses), referring to the benchmarking for the industrial efficiency of palm oil extraction (Menon, 2012).

Tabela 6. Selection of genetic gains estimates (SG) for palm oil productivity (PROD_OP), evaluated from the $6^{\text {th }}$ to the $9^{\text {th }}$ year after planting, in $39 \mathrm{~F} 1$ progenies, from crosses between female genitors of 'Manicoré'-originated American oil palm and male genitors of 'La Mé'-originated oil palms, based on the restricted selection of oil palm male genitors of LM2T e LM10T progenies.

\begin{tabular}{lcccc}
\hline Origin & Number of progenies & $\bar{X}_{\mathrm{S}}$ & $\mathrm{SD}$ & $\mathrm{SG}$ \\
\cline { 3 - 4 } & & & ${\left(\mathrm{kg} \mathrm{ha}^{-1} \text { per year }\right)^{(1)}}$ & \\
\hline LM2T & 15 & $5,800(5,399)$ & $338(314)$ & $281(262)$ \\
LM10T & 24 & $5,250(4,887)$ & & 5.1 \\
\hline
\end{tabular}

$\overline{\mathrm{X}}_{\mathrm{S}}$, estimates of the mean of the selected progenies; SD, selection differential. The genetic parameters $\overline{\mathrm{X}}_{\mathrm{S}}$, SD, and SG (kg ha ${ }^{-1}$ per year) are shown in the absolute scale and in values with $93.1 \%$ adjustment (in parentheses), referring to the benchmarking for the industrial efficiency of palm oil extraction (Menon, 2012). 
palm with 'Manicoré-originated American oil palm is greater than that of LM10T. These results confirm the possibility of immediate genetic gains in PROD OP with the selection only for males, enabling the immediate availability of this material to producers, until the period when the new multiplied parents reach the commercial seed production capacity.

Although the restrict selection for male genitors provide smaller genetic gain than the selection for both genitor sexes, this strategy do not require genotype multiplication to start the seed production of the improved hybrids. However, female genitors need to be multiplied to produce seed in a commercial scale, which requires approximately eight years (Gomes Junior et al., 2019). The selection of male parents (pisifera-type palm oil) is justified by the potential to produce a large number of seed from a single plant, since the production of pollen is high, in comparison with the potential of seed production from female genitor. In Papua New Guinea, using only five pisiferatype oil palm parents, more than 12 million teneratype seed were produced per year (Corley \& Tinker, 2016). As a result, gains are obtained in two stages, in the short term, with the selection restricted to male oil palm parents and in the medium (up to eight years) and long term (above eight years), with the selection practiced in the both genitor sexes.

According to Rethinam \& Murugesan (2018), American oil palm is a promising source of genetic resources, with desirable characteristics related to tolerance to biotic and abiotic stresses. Despite this fact, the cultivation of pure American oil palm is not economically viable due to its low productivity of mesocarp oil $\left(<1 \mathrm{Mg} \mathrm{ha}^{-1}\right.$ per year) in comparison to that of the oil palm (4 to $5 \mathrm{Mg} \mathrm{ha}^{-1}$ per year) (Cunha et al., 2012). These authors report that interspecific hybrids may reach about $90 \%$ of palm oil productivity. The current study showed that improved oil palm hybrids with oil productivity greater than $5 \mathrm{Mg} \mathrm{ha}^{-1}$ per year can be obtained by different selection strategies. This indicates their high performance and the possibility of launching a new cultivar in the short term (up to one year), with the restricted selection of LM 2T male parents, and cultivars with higher productivity in the medium (up to eight years) and long term (more than eight years), exploring interspecific reciprocal recurrent selection between 'Manicoré-originated
American oil palm population (female genitors) and 'La Mé'-originated oil palm population (male genitors).

\section{Conclusions}

1. The high values obtained for $\mathrm{F}$ estimates, heritabilities and Cvg / Cve ratios indicate favorable conditions for the palm oil production improvement in F1 interspecific hybrid progenies between female genitors of 'Manicoré'-originated American oil palm and male genitors of 'La Mé'-originated pisifera-type oil palms.

2. The genetic gains of palm oil production in interspecific hybrids can be obtained immediately with the restricted selection of the male genitors LM2T of 'La Mé-originated pisifera-type oil palm and, in the medium and long terms, greater genetic gains can be obtained with the interspecific reciprocal recurrent selection between parent populations of 'Manicoréoriginated American oil palm and 'La Mé'-originated oil palms.

3. The genetic correlations between the palm oil productivity with production of fresh fruit bunch and the palm oil content in fresh fruit bunch are high and positive; the indirect selection provides significant gains for the palm oil productivity, however, these gains are lower than those by direct selection.

\section{Acknowledgments}

To Conselho Nacional de Desenvolvimento Científico e Tecnológico (CNPq), for financial support (Projects 404815/2013-8 and 482.500/20093); to Fundação Amazônia de Amparo a Estudos e Pesquisas (Fapespa) (Project 141.308/2014); to Embrapa (Project 02.13.13.002.00.00); to Marborges Group; to Carlos Edmundo Quaresma (Group Marborges), for supervising the technical work related to the maintenance and evaluation of the HIE OxG experiments; to Embrapa researchers Alessandra de Jesus Boari (Phytopathology), Vinícius Ide Franzini and Wenceslau Geraldes Teixeira (Plant Nutrition), for technical contributions.

\section{References}

ALAIN, R. Huile de palme: défis renouvelés de la durabilité. 2020. Available at: <https://agritrop.cirad.fr/596686/1/42433210-f6075. pdf $>$. Acessed on: May 122020. 
ALVARES, C.A.; STAPE, J.L.; SENTELHAS, P.C.; GONÇALVES, J.L. de M.; SPAROVEK, G. Köppen's climate classification map for Brazil. Meteorologische Zeitschrift, v.22, p.711-728, 2013. DOI: https://doi.org/10.1127/09412948/2013/0507.

AMIRUDDIN, M.D.; NOOKIAH, R.; SUKAIMI, J.; HAMID, Z.A. Genetic variation and heritability estimates for bunch yield, bunch components and vegetative traits in oil palm interspecific hybrids. Journal of Agricultural Science and Technology, v.5, p.162-173, 2015. DOI: https://doi.org/10.17265/2161$6256 / 2015.03 .002$.

BAKOUMÉ, C.; GALDIMA, M.; TENGOUA, F.F. Experimental modification of reciprocal recurrent selection in oil palm breeding in Cameroon. Euphytica, v.171, art.235, 2010. DOI: https://oi.org/10.1007/s10681-009-0034-1.

BAKOUMÉ, C.; LOUISE, C. Breeding for oil yield and short oil palms in the second cycle of selection at La Dibamba (Cameroon). Euphytica, v.156, p.195-202, 2007. DOI: https://doi.org/10.1007/ s10681-007-9366-X.

BASTIDAS, S.; PEÑA, E.; REYES, R.; PÉREZ, J.; TOLOSA, W. Comportamiento agronómico del cultivar híbrido RC1 de palma de aceite (Elaeis oleifera $\mathrm{x}$ Elaeis guineensis) x Elaeis guineensis. Revista Corpoica - Ciencia y Tecnología Agropecuaria, v.8, p.5-11, 2007. DOI: https://doi.org/10.21930/rcta.vol8_num1_art:77.

BLACK, G.; SPARNAAIJ, L.D.; MENEDEZ, T. Breeding and inheritance in the oil palm (Elaeis guineensis Jacq.). Part II: Methods of bunch quality analysis. Journal of West Africa Institute of Oil Palm Research, v.4, p.146-155, 1963.

CORLEY, R.H.V.; TINKER, P.B. The oil palm. $5^{\text {th }}$ ed. Oxford: Wiley Blackwell, 2016. 692p. DOI: https://doi.org/10.1002/9781118953297.

CRUZ, C.D. Análise agrupada em blocos. In: CRUZ, C.D. Programa GENES: estatística experimental e matrizes. Viçosa: UFV, 2006a. p.97-103.

CRUZ, C.D. Genes software: extended and integrated with the R, Matlab and Selegen. Acta Scientiarum Agronomy, v.38, p.547$552,2006 b$.

CUNHA, R.N.V. da; LOPES, R. BRS Manicoré: híbrido interespecífico entre o caiaué e o dendezeiro africano recomendado para áreas de incidência do amarelecimento-fatal. Manaus: Embrapa Amazônia Ocidental, 2010. 3p. (Embrapa Amazônia Ocidental. Comunicado técnico, 85).

CUNHA, R.N.V.; LOPES, R.; ROCHA, R.; LIMA, W.; TEIXEIRA, P.; BARCELOS, E.; RODRIGUES, M.R.; RIOS, S.A. Domestication and breeding of the American oil palm. In: BORÉM A.; LOPES M.T.G.; CLEMENT, C.R.; NODA, H. (Ed.). Domestication and breeding: Amazonian species. Viçosa: Suprema, 2012. p.275-296.

FREITAS, A.F. de; LOPES, R.; CUNHA, R.N.V. da; PINA, A.J. de A.; RESENDE, M.D.V.; GOMES JÚNIOR, R.A. Genotypic values and genetic correlations for components and oil content of bunch of hybrids between caiaué and dendê. Colloquium Agrariae, v.17, p.79-92, 2021. DOI: https://doi.org/10.5747/ ca.2021.v17.n1.a422.
GOMES JR, R.A.; GURGEL, F. de L.; PEIXOTO, L. de A.; BHERING, L.L.; CUNHA, R.N.V. da; LOPES, R.; PINA, A.J. de A.; VEIGA, A.S. Evaluation of interspecific hybrids of palm oil reveals great genetic variability and potential selection gain. Industrial Crops and Products, v.52, p.512-518, 2014. DOI: https://doi.org/10.1016/j.indcrop.2013.10.036.

GOMES JUNIOR, R.A.; LOPES, R.; CUNHA, R.N.V. da; PINA, A.J. de A.; QUARESMA, C.E.; CAMPELO, R.D.; RESENDE, M.D.V. de. Selection gains for bunch production in interspecific hybrids between caiaué and oil palm. Pesquisa Agropecuária Brasileira, v.54, e00819, 2019. DOI: https://doi.org/10.1590/ S1678-3921.pab2019.v54.00819.

GOMES JUNIOR, R.A.; LOPES, R.; CUNHA, R.N.V. da; PINA, A.J. de A.; QUARESMA, C.E.; SANTOS, R.R.; RESENDE, M.D.V. de. Bunch yield of interspecific hybrids of American oil palm with oil palm in the juvenile phase. Crop Breeding and Applied Biotechnology, v.16, p.86-94, 2016. DOI: https://doi.org/10.1590/1984-70332016v16n2a14.

GOMES JUNIOR, R.A.; LOPES, R.; CUNHA, R.N.V. da; PINA, A.J. de A.; SILVA, M.P. da; RESENDE, M.D.V. de. Características vegetativas na fase juvenil de híbridos interespecíficos de caiaué com dendezeiro. Revista de Ciências Agrárias, v.58, p.27-35, 2015. DOI: https://doi.org/10.4322/rca.1590.

IUSS WORKING GROUP WRB. World Reference Base for Soil Resources 2014: international soil classification system for naming soils and creating legends for soil maps: update 2015. Rome: FAO, 2015. (FAO. World Soil Resources Reports, 106).

KRUALEE, S.; SDOODEE, S.; EKSOMTRAMAGE, T.; SEREEPRASERT, V. Correlation and path analysis of palm oil yield components in oil palm (Elaeis guineensis Jacq.). Kasetsart Journal - Natural Science, v.47, p.528-533, 2013.

LOPES, R.; CUNHA, R.N.V. da; RESENDE, M.D.V. de. Produção de cachos e parâmetros genéticos de híbridos de caiaué com dendezeiro. Pesquisa Agropecuária Brasileira, v.47, p.1496-1503, 2012. DOI: https://doi.org/10.1590/S0100204X2012001000012

MANDAL, P.K.; SUJATHA, G.; KUMAR, T.K. Qualitative analysis of interspecific hybrids of oil palm for bunch components and fatty acid composition. Journal of Plantation Crops, v.37, p.117-122, 2009.

MENON, N.R. Significance of oil extraction rate (OER) efficiency in a palm oil Mill. Palm Oil Engineering Bulletin, v.105, p.3538, 2012.

NOH, A.; RAFII, M.Y.; SALEH, G.; KUSHAIRI, A.; LATIF, M.A. Genetic performance and general combining ability of oil palm Deli dura x AVROS pisifera tested on inland soils. The Scientific World Journal, v.2012, art.792601, 2012. DOI: https://doi.org/10.1100/2012/792601.

NYOUMA, A.; BELL, J.M.; JACOB, F.; CROS, D. From mass selection to genomic selection: one century of breeding for quantitative yield components of oil palm (Elaeis guineensis Jacq.). Tree Genetics and Genomes, v.15, art.69, 2019. DOI: https://doi.org/10.1007/s11295-019-1373-2.

OECD-FAO Agricultural Outlook 2019-2028. Paris: OECD, 2019. Available at: $<$ https://www.oecd-ilibrary.org/docserver/agr 
outlook-2019-en.pdf?expires $=1624279431 \& \mathrm{id}=\mathrm{id} \&$ accname $=$ guest\&checksum=10562E553E740638BFAE801400ABBBB5>. Accessed on: Mar. 82021.

PIMENTEL-GOMES, F. Curso de estatística experimental. 15.ed. Piracicaba: Fealq, 2009. 451p.

PINA, A.J. de A. Experiências na produção para a cultura de palma de óleo na Amazônia: relato de experiências da Marborges Agroindústria S.A. (Moju - Pará). In: FREITAS, P.L. de; TEIXEIRA, W.G.T. (Ed.). Zoneamento agroecológico, produção e manejo para a cultura da palma de óleo na Amazônia. Rio de Janeiro: Embrapa Solos, 2010. p.189-204.

PINTO, S.S.; LOPES, R.; CUNHA, R.N.V. da; SANTOS FILHO, L.P. dos; MOURA, J.I.L. Produção e composição de cachos e incidência do anel vermelho em híbridos interespecíficos de caiaué com dendezeiro no sul da Bahia. Agrotrópica, v.31, p.5$16,2019$.

RAMALHO FILHO, A.; MOTTA, P.E.F. da; NAIME, U.J.; GONÇALVES, A.O.; TEIXEIRA, W.G. Zoneamento agroecológico para a cultura da palma de óleo nas áreas desmatadas da Amazônia Legal. In: RAMALHO FILHO, A.; MOTTA, P.E.F. da (Ed.). Zoneamento agroecológico, produção e manejo para a cultura da palma de óleo na Amazônia. Rio de Janeiro: Embrapa Solos, 2010. p.57-68.

RAO, V.; SOH, A.C.; CORLEY, R.H.V.; LEE, C.H.; RAJANAIDU, N.; TAN, Y.P.; CHIN, C.W.; LIM, K.C.; TAN, S.T.; LEE, T.P.; NGUI, M. A critical reexamination of the method of bunch quality analysis in oil palm breeding. PORIM occasional paper, n.9, p.1-26, 1983.
RETHINAM, P.; MURUGESAN, P. Global perspective of germplasm and breeding for seed production in oil palm. International Journal of Oil Palm, v.10, p.17-34, 2018.

REY B., L.; GÓMES C., P.L.; AYALA D., I.; DELGADO A., W.; ROCHA S., P. Colecciones genéticas de palma de aceite Elaeis guineensis (Jacq.) y Elaeis oleifera (H.B.K.) de Cenipalma: características de importância para el sector palmicultor. Palmas, v.25, p.39-48, 2004. N. especial.

RIOS, S. de A.; CUNHA, R.N.V. da; LOPES, R.; BARCELOS, E.; ROCHA, R.N.C. da; LIMA, W.A.A. de. Correlation and path analysis for yield components in dura oil palm germplasm. Industrial Crops and Products, v.112, p.724-733, 2018. DOI: https://doi.org/10.1016/j.indcrop.2017.12.054.

SANTOS, H. G. dos; JACOMINE, P. K.T; ANJOS, L.H.C. dos; OLIVEIRA, V.Á. de; LUMBRERAS, J.F.; COELHO, M.R.; ALMEIDA, J.A. de; ARAÚJO FILHO, J.C. de; OLIVEIRA, J.B. de; CUNHA, T.J.F. Sistema Brasileiro de Classificação de solos 5.ed. rev. e ampl. Brasília: Embrapa, 2018. 356p.

USDA. United States Department of Agriculture. Oil seeds: world markets and trade. 2021. Available at: <https://apps.fas.usda.gov/ psdonline/circulars/oilseeds.pdf $>$. Accessed on: Aug. 32021.

WOITTIEZ, L.S.; van WIJK, M.T.; SLINGERLAND, M.; van NOORDWIJK, M.; GILLER, K.E. Yield gaps in oil palm: a quantitative review of contributing factors. European Journal of Agronomy, v.83, p.57-77, 2017. DOI: https://doi.org/10.1016/j. eja.2016.11.002. 